\title{
On the issue of forming an information and analytical database for the greening of water use in the zone of risky agriculture
}

\author{
T.B. Putivskaya ${ }^{1 *}$ \\ Saratov State Agrarian University named after N.I. Vavilov, 410012, 1, Teatralnaya sq., Saratov, \\ Russian Federation
}

\begin{abstract}
In areas of risky agriculture, the practical solution to the problem of improving the quality characteristics of the environment can be the intersectoral formation of organizations and informal institutions that jointly solve the problems of putting into circulation and further use of irrigated land. In the context of global climate change, the agricultural sector, despite some innovative solutions and applied technologies, remains the most dependent and vulnerable. The main part of Russian agricultural products is produced in areas with insufficient and (or) uneven humidification regimes, and the problem of climate change and its impact is as relevant as for other countries. The current conditions dictate the need to create an effective system of organizational and economic relations between rural producers, the land reclamation complex and public administration bodies. The result of their functioning should be the transition of rural areas to sustainable development, which determines the reduction of risks from climate change and the increase in the attractiveness of living and employment of people in rural areas.
\end{abstract}

\section{Introduction}

In the zone of risky agriculture, the stabilization of the agricultural sector of the economy and the improvement of the living conditions of the rural population are directly related to the further development of irrigation reclamation. In the context of import substitution and export-oriented agricultural production, irrigation acts as a significant factor in socio-economic development and ensuring food security. The lack of developed industrial zones, objects of active tourism industry, large sources of natural resources and infrastructure facilities makes agricultural production the main type of labor activity and employment of most residents of rural areas. The area of reclaimed land with low productivity cannot have a decisive impact on neutralizing the risk of adverse weather conditions and providing the country's population with food. The effectiveness of the use of irrigated land depends on the organization of irrigation of agricultural crops. Water quality control is an important point for determining the level of pollutants and subsequent water purification to reduce (eliminate) negative effects on crop growth. To solve the issues of

\footnotetext{
*Corresponding author: putivsckaja@yandex.ru
} 
functioning of intersectoral formations and organizational structures and to find the optimal balance of market mechanisms and state regulation of the integration of intersectoral interests of the agricultural and water sectors of the economy, it is necessary to develop a model of the organizational and economic mechanism of influence on the participants. By improving the quality characteristics of irrigation water, reducing the wear of equipment, and increasing the productivity of agricultural crops, positive environmental and economic changes can be expected.

\section{Methods}

The work uses a systematic, integrated approach to the study of ecological and economic problems and tasks of agricultural production development. The research used methods and approaches used in the analysis and diagnosis of the ecological and economic state and development of agricultural enterprises and rural areas, resources, mainly of a natural nature, necessary for conducting effective agricultural production, provided that the qualitative characteristics of the environment are preserved. To develop correction coefficients for tariffs for irrigated water, the method of groupings with attributive grouping features was used and correctly.

\section{Results}

For high-performance agriculture, there is no ideal formula for the content of substances in irrigation water. Each water source has individual characteristics, and if the concentration of nutrients, alkalinity, or residual ions in the irrigation water is within the limits of acceptable impacts, most environmental problems can be avoided. Water quality control is an important point for determining the level of pollutants and its subsequent water purification to reduce (eliminate) negative effects on the growth of crops. Standard studies of the quality characteristics of irrigation water reveal the total salinity, alkalinity, content of toxic salts, chlorine ions, bicarbonates, and so on $[3,10]$.

According to environmental criteria, water is classified as: 1. suitable for irrigation; 2. limited suitable. The assessment of water according to the ecological principle is carried out according to three groups of signs:

1. With the presence of substances with a positive effect in certain quantities and necessary for agricultural crops: nitrogen, oxygen, trace elements;

2. With the presence of substances that have a negative effect: heavy metal salts, phenols, oil and petroleum products, cyanides, pesticides. pathological bacteria and organisms, radioactive substances;

3 . With the content of suspended particles of mineral and organic origin, depending on the size and compliance with the accepted standards (maximum permissible indicators): the size of the suspensions, the concentration level.

The standard characteristics of untreated water include:

1. rigidity that contributes to clogging and blocking of irrigation system equipment;

2. salinity, which can have a negative impact on the availability of water for plants and lead to their dehydration;

3. the alkaline index, which determines the availability of nutrients and the risk of blocking irrigation systems;

4. excessive amounts of certain nutrients can damage crops and reduce their yield.

The benefits of using clean irrigation water are due to the reduction of pollutants, unwanted minerals, and the localization of nutrients. In addition, if crops are grown in soil where the microbial community is vital, the use of polluted water can cause environmental 
and economic damage with the emergence of a chain reaction that reduces the amount of nutrients contained in the soil and available for beneficial microorganisms [3]. The formation of an information and analytical base of indicators that take into account the identified problems and conditions for the successful functioning of land reclamation complexes in modern conditions is an important starting potential for the use of information technologies in the agricultural sector. The block of environmental and resource-saving indicators is supplemented with an environmental block, which contains indicators that take into account the qualitative (ecological) composition of irrigation water. The system of regional environmental and economic indicators includes economic indicators that are balanced with the environment and an indicator of environmental well-being, interconnected according to the "load - state - response" scheme. The criteria for environmentally safe water use should be the amount of water saved, reducing the amount of pollutants while increasing output, and a differentiated approach to setting irrigation water tariffs will ensure a greater economic effect compared to environmental costs $[8,10]$.

Data (table.1.) represent a developed system of parameters that take into account the degree of danger of water of different composition and its permissibility for irrigation. Agricultural crops are characterized by an 8-10-fold range of stability, which allows you to expand the range of salinity of irrigation water acceptable for irrigation, if there is no restriction on soils.

The emerging organizational and economic relations between agricultural producers, land reclamation (water management) complex and public administration bodies are formed according to the territorial principle of water user associations, which jointly resolve issues of mutual relations regarding the implementation of environmental and resource-saving measures $[4,5]$.

Table 1. Irrigation water quality classes (data in the numerator) and calculated correction factors (data in the denominator) for irrigation water tariffs*.

\begin{tabular}{|c|c|c|c|c|}
\hline \multicolumn{5}{|c|}{ Soil-reclamation classification of irrigation water quality } \\
\hline $\begin{array}{l}\text { non- } \\
\text { hazar } \\
\text { dous }\end{array}$ & low-hazard & $\begin{array}{l}\text { moderate- } \\
\text { hazardous }\end{array}$ & hazardous & $\begin{array}{c}\text { Average } \\
\text { value of the } \\
\text { coefficient }\end{array}$ \\
\hline \multicolumn{5}{|c|}{ 1. Water salinity, g / I for soil irrigation } \\
\hline \multicolumn{5}{|c|}{ 1) with heavy mechanical composition (PPK more than 30$)$} \\
\hline $\begin{array}{c}0,2- \\
0,5 \\
0,75\end{array}$ & $\begin{array}{c}0,5-0,8 \\
1\end{array}$ & $\begin{array}{c}0,8-1,2 \\
1,25\end{array}$ & $\begin{array}{c}\text { More than } 1,2 \\
1,50\end{array}$ & 0,97 \\
\hline \multicolumn{5}{|c|}{ 2) with medium mechanical composition (PPK 15-30) } \\
\hline $\begin{array}{c}0,2- \\
0,6 \\
0,63\end{array}$ & $\begin{array}{c}0,6-1,0 \\
1\end{array}$ & $\begin{array}{c}1,0-1,5 \\
1,15\end{array}$ & $\begin{array}{c}\text { More than } 1,5 \\
1,25\end{array}$ & 0,84 \\
\hline \multicolumn{5}{|c|}{ 3) with a light mechanical composition of soils (PPK less than 15) } \\
\hline $\begin{array}{c}0,2- \\
0,7 \\
0,58\end{array}$ & $\begin{array}{c}0,7-1,2 \\
1\end{array}$ & $\begin{array}{c}1,2-2,0 \\
1,05\end{array}$ & $\begin{array}{c}\text { More than } 2 \\
1,15\end{array}$ & 0,77 \\
\hline \multicolumn{5}{|c|}{$\begin{array}{l}\text { 2.Assessment of water quality according to the degree of danger of development of } \\
\text { processes in soils }\end{array}$} \\
\hline \multicolumn{5}{|c|}{ 1) chloride salinity, mg-eq/l } \\
\hline $\begin{array}{l}\text { Less } \\
\text { than } \\
0,75\end{array}$ & $\begin{array}{c}2,0-4,0 \\
1\end{array}$ & $\begin{array}{c}4,0-10,0 \\
1,25\end{array}$ & $\begin{array}{c}\text { More than } 10 \\
1,75\end{array}$ & 1,03 \\
\hline
\end{tabular}




\begin{tabular}{|c|c|c|c|c|}
\hline \multicolumn{5}{|c|}{ Soil-reclamation classification of irrigation water quality } \\
\hline $\begin{array}{l}\text { non- } \\
\text { hazar } \\
\text { dous }\end{array}$ & low-hazard & $\begin{array}{l}\text { moderate- } \\
\text { hazardous }\end{array}$ & hazardous & $\begin{array}{c}\text { Average } \\
\text { value of the } \\
\text { coefficient }\end{array}$ \\
\hline \multicolumn{5}{|c|}{ 2) sodium salinity, mg-eq/l } \\
\hline $\begin{array}{c}\text { Less } \\
\text { than } \\
0,5 \\
0,75\end{array}$ & $\begin{array}{c}0,5-1,0 \\
1\end{array}$ & $\begin{array}{c}1,0-2,0 \\
1,25\end{array}$ & $\begin{array}{c}\text { More than } 2 \\
1,75\end{array}$ & 1,03 \\
\hline \multicolumn{5}{|c|}{ 3) magnesium salinization, $\mathrm{mg}-\mathrm{eq} / \mathrm{l}$} \\
\hline $\begin{array}{c}\text { Less } \\
\text { than } \\
1,0 \\
0,75\end{array}$ & $\begin{array}{c}1,0-1,5 \\
1\end{array}$ & $\begin{array}{c}1,5-2,5 \\
1,25\end{array}$ & $\begin{array}{c}\text { More than } 2,5 \\
1,75\end{array}$ & 1,03 \\
\hline \multicolumn{5}{|c|}{ 3. Water quality for irrigation of crops of different salt resistance } \\
\hline \multicolumn{5}{|c|}{ 1) the sum of cations, mg-eq/l } \\
\hline $\begin{array}{c}0-10 \\
0,61\end{array}$ & $\begin{array}{c}10-20 \\
1\end{array}$ & $\begin{array}{c}30-50 \\
1,50\end{array}$ & $\begin{array}{c}\text { More than } 50 \\
1,80\end{array}$ & 1,17 \\
\hline \multicolumn{5}{|c|}{ 2) content of $\mathrm{Na}+$ and $\mathrm{K}+, \%$} \\
\hline $\begin{array}{c}0-65 \\
0,47\end{array}$ & $\begin{array}{c}65-95 \\
1\end{array}$ & $\begin{array}{c}95-100 \\
1,50\end{array}$ & $\begin{array}{c}\text { More than } 100 \\
1,75\end{array}$ & 1,24 \\
\hline \multicolumn{5}{|c|}{ 4. Criteria for environmental assessment of soilconditions } \\
\hline \multicolumn{5}{|c|}{ 1) increase in the content of easily soluble salts, $\mathrm{g} / 100 \mathrm{~g}$ of soil } \\
\hline $\begin{array}{c}\text { Up to } \\
0,1 \\
0,50\end{array}$ & $\begin{array}{c}0,1 \ldots 0,4 \\
1\end{array}$ & $\begin{array}{c}0,4 \ldots 0,8 \\
1,25\end{array}$ & $\begin{array}{c}\text { More than } 0,8 \\
1,50\end{array}$ & 1,08 \\
\hline \multicolumn{5}{|c|}{ 5. Indicators for assessing the degree of chemical pollution of water bodies } \\
\hline \multicolumn{5}{|c|}{ 1) MPC chemicals for hazard classes } \\
\hline \multicolumn{5}{|c|}{1 and 2 hazard classes } \\
\hline $\begin{array}{c}1 \\
0,75\end{array}$ & $\begin{array}{c}1 \ldots 5 \\
1\end{array}$ & $\begin{array}{c}5 \ldots 10 \\
1,50\end{array}$ & $\begin{array}{c}\text { More than } 10 \\
2,0\end{array}$ & 1,42 \\
\hline \multicolumn{5}{|c|}{ 3and 4 hazard classes } \\
\hline $\begin{array}{c}1 \\
0,65\end{array}$ & $\begin{array}{c}1 \ldots 50 \\
1\end{array}$ & $\begin{array}{c}50 \ldots 100 \\
1,25\end{array}$ & $\begin{array}{c}\text { More than } 100 \\
1,50\end{array}$ & 1,13 \\
\hline \multicolumn{5}{|c|}{ 2) $\mathrm{COD}, \mathrm{mg} \mathrm{O} 2 /$ liter } \\
\hline $\begin{array}{c}\text { No } \\
0,55\end{array}$ & $\begin{array}{c}0 \ldots 10 \\
1\end{array}$ & $\begin{array}{c}10 \ldots 20 \\
1,25\end{array}$ & $\begin{array}{c}20 \ldots 30 \\
1,50\end{array}$ & 1,10 \\
\hline \multicolumn{5}{|c|}{ 3) biogenic substances: } \\
\hline \multicolumn{5}{|c|}{ nitrites, MPC } \\
\hline $\begin{array}{l}\text { Less } \\
\text { than } 1 \\
0,55\end{array}$ & $\begin{array}{c}\text { More than } 3 \\
1\end{array}$ & $\begin{array}{c}\text { More than } 5 \\
1,50\end{array}$ & $\begin{array}{c}\text { More than } 10 \\
2,0\end{array}$ & 1,35 \\
\hline \multicolumn{5}{|c|}{ nitrates, MPC } \\
\hline $\begin{array}{c}\text { Less } \\
\text { than } 1 \\
0,55\end{array}$ & $\begin{array}{c}\text { More than } 5 \\
1\end{array}$ & $\begin{array}{c}\text { More than } 10 \\
1,50\end{array}$ & $\begin{array}{c}\text { More than } 20 \\
2,0\end{array}$ & 1,35 \\
\hline \multicolumn{5}{|c|}{ Crop yield potential, \% } \\
\hline 100 & $100-75$ & $75-50$ & $50-0$ & \\
\hline
\end{tabular}


The existing relations provide an opportunity to: 1) reducing costs due to the agglomeration effect; 2) systematic dissemination of innovation and digitalization of processes to ensure environmental safety in conditions of water scarcity based on simulation modeling and multi-criteria analysis methods. As a result, the strategy of organizing this interaction is based on the need to create an interconnected system, the main goal of which is aimed at positive environmental and economic changes within agglomerations, taking into account the sustainability of development [4].

The optimal balance of market mechanisms and state regulation of the integration of intersectoral interests of the agricultural and water sectors requires further research of the organizational and economic mechanism for regulating relations between the subjects of economic activity of the land reclamation complex. The new territorial integration spaces create new conditions for the development of small and medium-sized businesses, and it seems productive to develop a science-based policy for the integrated development of rural areas, taking into account environmental, economic, institutional and territorial factors.

\section{Discussion}

In the context of global climate change and its impact on the environment, there is no possibility of using intensive agricultural technologies, highly productive varieties of agricultural crops, adaptive landscape farming systems. The agricultural sector, despite some innovative solutions and applied technologies, remains the most dependent and vulnerable to the climate. The increase in adverse and dangerous phenomena, the processes of land desertification, and the decline in biodiversity is typical for the whole world (especially for African countries, countries of South-East Asia and Southern Europe). 28 regions of Russia are subject, to varying degrees, to the processes of land degradation, for which there are no territorial restrictions, These are the south of Russia, the Volga region, the Southern Urals, the Altai Territory and other regions that make up the main grain belt of the country. The shortage of crop production in grain equivalent amounts to 47.3 million tons per year. The main part of Russian agricultural products is produced in areas with insufficient and (or) uneven humidification regimes, and the problem of climate change and its impact is as relevant as for other countries. The lack of precipitation is observed on $80 \%$ of arable land [3]. Reducing the area of forests and increasing emissions of harmful substances into the atmosphere (the annual mass of emissions from stationary sources is 32 million tons) contributes to the determination of the structure of heat exchange and moisture exchange, the violation of the radiation balance of agricultural landscapes, and the weakening of their assimilation potential. The incoming solar energy is largely consumed for overheating and dehydration of the territory. Currently, $65 \%$ of arable land, $28 \%$ of hayfields and $50 \%$ of pastures in Russia are subject to a whole range of negative impacts: these are droughts, dry winds, and dust storms. Low forest cover of the territory and a high degree of ploughing $(60-80 \%)$ leads to an increase in erosion processes with an annual loss of humus on arable land up to $0.62 \mathrm{t} /$ ha. [4] Under these conditions, a particularly valuable category of transformed agricultural land is reclaimed land. The area of reclaimed land (9.47 million hectares, including $49 \%$ of irrigated land and $51 \%$ of drained land). Agricultural production uses 7.08 million hectares of reclaimed land (75\% of the available land), including 3.89 million hectares of irrigated and 3.19 million hectares of drained land. Reclaimed land, which occupies $8 \%$ of the arable land area, produces up to $70 \%$ of vegetables, potatoes and melons, $100 \%$ of rice, and about $20 \%$ of forage crops [2]. Low productivity in the agricultural sector cannot have a decisive impact on neutralizing the risk of adverse weather conditions and providing the country's population with food and other consumers with domestic agricultural products. The search for ways out of the current situation, which is typical for many regions of the world, remains an important problem of 
ecological and economic development. For the sustainable functioning of agriculture, a more intensive interaction of agronomy and ecosystem ecology is necessary. The sustainability of ecological and economic development can be achieved by effective and integrated management of the agricultural system. In essence, the management of agricultural production is the management of an established agricultural system. In turn, the creation of such systems pursues economic goals. The information and analytical base for assessing the efficiency of agricultural systems should contain the necessary qualitative indicators: resource intensity and waste intensity of production, environmental costs, and economic damage. One of the important reasons for not achieving the set goals is the lack of consideration of environmental criteria and characteristics and the decline in agricultural culture. According to the Ministry of Agriculture of Russia [1, 2], the area of unused agricultural land in 2021 is 44 million hectares, arable land-20 million hectares. The development of a draft separate state program for the development of the reclamation complex of Russia for 2021-2030 involves the involvement of at least 12 million hectares in the turnover of agricultural land, the collection and systematization of data on 383 million hectares of agricultural land [1]. To: provide the country's population with food and maintain the volume of exports of domestic agricultural products, the total demand of the agricultural sector for water resources is $40 \mathrm{~km} .3$ per year. In accordance with the water use plans (as of 2018), irrigation was carried out on an area of 1386.8 thousand hectares. The efficiency of the use of irrigated land and irrigation water depends on the organizational and environmental-economic factors of irrigation.

The barriers to the introduction of land into circulation and its further use are the assimitricity of information about their quality, composition and forms of ownership, the deterioration of fixed assets of irrigation systems by $78 \%$ and the unresolved problems of improving the quality of irrigation water[9,10].

Some directions of solving the identified problems on the part of the Government of Russia and the Ministry of Agriculture of Russia are presented (Table.2) [7, 8].

Table 2. Directions for solving the problems of putting agricultural land into circulation for land reclamation*.

\begin{tabular}{|c|}
\hline Directions for solving the identified problems \\
\hline $\begin{array}{l}\text { - accounting of information on reclaimed agricultural land plots based on the use of digital } \\
\text { technologies with the maintenance of a register; }\end{array}$ \\
\hline $\begin{array}{l}\text { - identification of unused agricultural land for its intended purpose, suitable for involvement in } \\
\text { economic turnover through interaction with the state land supervision; }\end{array}$ \\
\hline $\begin{array}{l}\text { - the final stage of actions to establish the boundaries of particularly valuable agricultural land with } \\
\text { high productivity, the misuse of which is not allowed by the current legislation; }\end{array}$ \\
\hline $\begin{array}{l}\text { - strengthening environmental control over the amount of agrochemicals and pesticides in the } \\
\text { discharged wastewater and addressing the issue of wastewater treatment before its discharge into } \\
\text { water bodies; }\end{array}$ \\
\hline $\begin{array}{l}\text { - ensuring active interaction with relevant departments in the formation of requests for subsidies for } \\
\text { land reclamation activities; }\end{array}$ \\
\hline $\begin{array}{l}\text { - making additions about the main characteristics of the reclaimed and / or reclaimed land plot in the } \\
\text { Unified State Register of Real Estate; }\end{array}$ \\
\hline $\begin{array}{l}\text { strengthening the integration of regional and interdisciplinary cooperation in priority research of land } \\
\text { reclamation science, engineering and technology on the basis of existing research institutes and } \\
\text { educational institutions; }\end{array}$ \\
\hline $\begin{array}{l}\text { - attraction of financial resources for the formation of the material and technical base of land } \\
\text { reclamation and support of scientific and technological projects and innovations; }\end{array}$ \\
\hline $\begin{array}{l}\text { - creation of the Federal Research Center "Melioration and Water Management of the Agro-industrial } \\
\text { complex" for solving science-intensive tasks of a fundamental and applied nature. }\end{array}$ \\
\hline
\end{tabular}




\section{Conclusion}

Climate aridization, reduced ecosystem capacity for self-regulation and natural recovery, freshwater scarcity, reduced biodiversity, soil degradation and erosion, a significant increase in unpredictable adverse hazards, and other pressing issues are largely due to climate change. The further aggravation of these problems is predicted by leading climatologists. In Russia, not only in the zones of risky agriculture, but also in the Central regions of Russia and in the Volga region, almost every second or third year has become arid, the risk of dust storms and desertification of territories has increased. Reclamation measures in areas of risky farming allow to level the current situation. According to the conducted quantitative analysis of the state of the reclamation complex of Russia and the volume of agricultural products produced on reclaimed lands, it can be concluded that the potential for putting agricultural land into circulation and organizing the production of agricultural products with high ecological and economic efficiency. Trends in the development of environmental risks and negative impacts of irrigation reclamation are evaluated. The directions of solutions proposed by the author, formulated in the article of priority tasks, will allow to develop specific proposals for improving irrigation technology and techniques, assessing the volume of irrigation water of standard quality, using digital technologies to ensure environmental safety in conditions of water scarcity on the basis of simulation modeling and multi-criteria analysis methods for effective water resources management. The benefits of using clean irrigation water are due to the reduction of environmental and economic damage from the resulting chain reactions, which reduce the amount of nutrients and beneficial microorganisms contained in the soil and available for crops. The new territorial integration spaces create conditions for the development of small and medium-sized businesses, and it seems productive to develop a science-based policy for the integrated development of rural areas, taking into account environmental, economic, institutional and territorial factors. The functioning of intersectoral formations and organizational structures and finding the optimal balance of market mechanisms and state regulation of the integration of the interests of the agricultural and water sectors of the economy require further research on the organizational and economic mechanism for regulating relations. The proposed method is universal and can be applied to any territory with some adjustments.

\section{References}

1. Draft state program on the involvement of agricultural land in the turnover and the development of the reclamation complex for 2021-2030 (Internet Portal regulation, 2020)

2. Topical issues of the development of the meliorative complex of low-water regions of the Russian Federation (2010)

3. B. Argo, P. Fisher, How irrigation water quality affects crops (2008)

4. E. A. Podsevatkina, T. B. Putivskaya, Agricultural scientific Journal, 10 (2017)

5. T. B. Putivskaya, L. A. Voloshchuk, S. I. Tkachev, E. A. Podsevatkina, IOP Conference Series: Earth and Environmental Science (2021)

6. The strategy of scientific and technological development of Russia until 2025 (2021)

7. Federal Law "On Land Reclamation" (2020)

8. The State program of effective involvement in the turnover of agricultural lands and the development of the reclamation complex of the Russian Federation № 371 (2021)

9. Types of reclamation activities and works (Moscow Standarinform, 2019)

10. Water flow measurement in hydromelioration and water economic systems (2020) 